\title{
Pragmatic Licensing of Czech SuperStrong Negative Polarity Items: An Experimental Study ${ }^{1}$
}

\begin{abstract}
In this study, we report an experiment focusing on pragmatic factors (unlikelihood presupposition) in licensing of Czech superstrong negative polarity items.
\end{abstract}

Keywords

NPIs, scalar particles, alternatives, formal semantics, experimental linguistics

\section{Introduction}

In this study, we focus on the pragmatic and semantic properties of the Negative Polarity Item (NPI) ani in Czech + its associated expression. To frame our arguments, we begin with stating empirical properties of this expression. It seems that (as in many other languages) this expression lives a double life: as (i) either a scalar/additive particle; or (ii) a conjunction. One basic example showing the conjunctive usage of ani is in (1). In this case, ani works like English nor (modulo the negative concord difference between the two languages),

\footnotetext{
${ }^{1}$ We would like to thank the audience of Sinfonija 11 in Krakow for many valuable questions and comments. The article profited from many comments by two anonymous reviewers whom we would like to thank a lot as well. Loren A. Billings helped us very much with the final version of the article and we would like to thank him too. Finally, we are happy to acknowledge that the research was supported by a Czech Science Foundation (GAČR) grant to the Department of Linguistics and Baltic Languages at the Masaryk University in Brno (GA17-16111S) and by the Support student research at the Department of Linguistics and Baltic Languages (MUNI/A/0791/2017).
} 
requiring negation on the predicate and conjoining basically all types of constituents (but of the same type). Alongside the conjunction sub-type in (1), there is an additive usage of ani in (2), with the sentence implicating/presupposing that someone else (i.e., in addition to Petr) didn't come to the party as well and out of the blue doesn't bear any scalar presuppositions.
(1) neměl
otce
ani matku
NEG-have-3SG.M.PST father-SG.M.ACC nor mother-SG.F.ACC
'He had neither a father nor a mother.'
(2) na večírek nepřišel ani Petr
to party-SG.M.ACC NEG-come-3SG.M.PST even Petr-SG.M.NOM
'Even Petr didn't come to the party'.

In this article, we focus on the third type of ani, exemplified in (3), the scalar particle ani usually (as in the example) associated with expressions denoting minimal elements (the most frequent collocations of ani in Czech National Corpus (SYN2010) are ani slovo 'not even a word', ani jeden 'not even one', ani trochu 'not even a bit' and ani jedenkrát 'not even once'). The scalar ani usually requires clause-mate negation, but the nature of its licensing is semantic, not syntactic. For Polish syntactic and semantic constraints on similar NPIs see Błaszczak (2001); for Czech see Dočekal and Dotlačil (2016, 2018). In this article, we will report the pragmatic properties of scalar ani licensing (and will base our description mainly on experimental results). It is maybe possible to unify the second type of ani (additive) with its third type (scalar), but as this article is mainly a report on an experiment, we don't aspire to such a theoretical goal. $^{2}$

(3) nezkazil se ani jediný výrobek

NEG-go-rotten-3SG.M.PST SE even one product-SG.M.NOM

'Not even single product got rotten.'

The structure of the article is the following: in Section 1.1 we introduce the theoretical tools we need; in section 2 we report the results of the experiment on Czech NPIs; Section 3 summarizes our findings.

\subsection{Theoretical background}

In this subsection, we introduce the framework we use. Our approach is a basically pragmatic theory of NPI licensing and stems from the seminal work of

\begin{tabular}{|c|c|c|c|c|c|}
\hline 3 & third person & GEN & genitive & NEG & negation, negative \\
\hline ACC & accusative & INF & infinitive & NOM & nominative \\
\hline COMP & complementizer & INS & instrumental & PL & plural \\
\hline $\mathrm{F}$ & feminine & M & masculine & PST & past \\
\hline FUT & future & $\mathrm{N}$ & neuter & SG & singular \\
\hline
\end{tabular}


Krifka (1995). The pragmatic theory of NPI licensing is currently one of the standard approaches to polarity effects in natural language, although more traditional semantic theories (as Zwarts 1998) are still used too. We adopt the pragmatic stance since it allows us to deal with NPI licensing even in cases where the alternatives used for the computation are not logically related to the target sentence. As far as we are aware, such cases are hard to deal with purely semantic approaches to polarity effects.

The exact semantic properties of scalar ani follow from its polarity nature: ani is licensed in semantics and requires the strongest type of NPI environment, a so-called anti-morphic environment which licenses superstrong NPIs, (Krifka 1995; Zwarts 1998; Gajewski 2011). An operator O is anti-morphic if it meets the two following logical requirements:

1. it is anti-additive which means that $\mathrm{O}$ verifies the predicate-logic biconditional $O(P(x) \vee Q(x)) \equiv O(P(x)) \wedge O(Q(x))$ - the definition of anti-additive logical strength (Zwarts 1998: 222). Among the expressions of natural language, which are anti-additive, are sentential negation, negative quantifiers in non negative concord languages, and universal quantifiers. Universal quantifiers are anti-additive because the following predicate-logic equivalence holds:

$\forall \mathrm{x}((\mathrm{P}(\mathrm{x}) \vee \mathrm{Q}(\mathrm{x})) \rightarrow \mathrm{R}(\mathrm{x})) \equiv(\forall \mathrm{x}(\mathrm{P}(\mathrm{x}) \rightarrow \mathrm{R}(\mathrm{x})) \wedge \forall \mathrm{x}(\mathrm{Q}(\mathrm{x}) \rightarrow \mathrm{R}(\mathrm{x})))$ - where

$\forall x(P(x) \rightarrow R(x))$ formalizes natural language universal quantifier in a subject position, the predicate $P(x)$ formalizes the restriction and $R(x)$ the nuclear scope, as usual. Another environment which is at least formally antiadditive is the material implication since the following propositional logic equivalence is valid: $((p \vee q) \rightarrow r) \equiv((p \rightarrow r) \wedge(q \rightarrow r))$. But the material implication is not the most suitable formalization of natural language conditionals (as is well known, see von Fintel (1999) for a classic linguistic reflection), which is one of the reasons that Gajewski (2005: 62) classifies antecedents of conditionals as Strawson anti-additive, not simply anti-additive. Nevertheless, neither a universal quantifier nor an antecedent of a conditional seems to license ani. But to be sure about it, we tested the licensing of ani in the antecedent clauses of conditionals, and the experiment confirmed that ani isn't licensed there (see Section 2.1.2 for details). For these reasons, we classify ani as a superstrong NPI requiring an anti-morphic environment on top of the anti-additive logical property.

2. An operator is anti-morphic if (it is anti-additive plus) applied to a negation of some expression equivalent to a negation of the operator applied to the (non-negated) version of the expression: $\mathrm{O}(\neg \mathrm{X})=\neg \mathrm{O}(\mathrm{X})$. Classical verbal negation (interpreted as logical negation) is, of course, anti-morphic since $\neg(\neg \mathrm{X})$ $=\neg \neg(\mathrm{X})$. This doesn't hold for a universal quantifier since $\neg \forall \mathrm{x}[\mathrm{P}(\mathrm{x}) \rightarrow \mathrm{Q}(\mathrm{x})]$. " $\mathrm{x}[\mathrm{P}(\mathrm{x}) \rightarrow \neg \mathrm{Q}(\mathrm{x})]$ which is the reason for a superstrong NPI one bit in (4) being licensed only by the verbal negation but not by the downward entailing 
(and anti-additive) quantifier every student (example adapted from Zwarts 1998: 232). ${ }^{3}$

(4) a. John wasn't one bit happy about these facts.

b. ${ }^{\star}$ Every student was one bit happy about these facts.

The superstrong nature of ani NPIs explains their ability to be licensed in the complements of negated Neg-raising verbs as opposed to non-Neg-raising verbs, see the contrast in (5a) vs. (5b), experimentally verified for Czech in Dočekal and Dotlačil (2016). Neg-raising predicates (unlike non-Neg-raisers as verbs of communication or causation) do share the "transfer of negation" property with anti-morphic environments: $\mathrm{x} \neg$ wants $p$ ceteris paribus implies that $\mathrm{x}$ wants $\neg p$ (see Gajewski 2007). ${ }^{4}$

a. Petr

nechce,

aby se ztratila

Petr-SG.M.NOM NEG-want-3SG.M

ani jedna knížka

z knihovny.

even one book-SG.F.NOM from library-SG.F.GEN

'Petr doesn't want even one book from the library to be missing.'

b. ${ }^{*}$ Petr neř́kal, že se ztratila

Petr-SG.M.NOM NEG-say-3SG.M.PST that SE lost-3SG.F.FUT

ani jedna knížka z knihovny.

even one book-SG.F.NOM from library-SG.F.GEN

'Petr didn't say that even one book from the library got lost.'

Even if the semantic sensitivity of ani NPIs was established before, the exact nature of its pragmatic behaviour wasn't thoroughly tested, so we designed an experiment to check the pragmatic (likelihood) properties of ani. Now we will introduce the theoretical assumptions behind the experiment. We follow the line of the analysis presented in Krifka (1995), Lahiri (1998), and Crnič (2011). The theoretical ingredients we need are the following:

i. NPIs are licensed both in semantics (in our case by anti-morphic operators) and pragmatics;

ii. NPIs introduce alternatives which in case of strong and superstrong NPIs are integrated into the truth-conditions of their respective sentences (the prejacent) via covert pragmatic operator close in meaning to English even;

- The core meaning contribution of the covert even is its unlikelihood presupposition, e.g., a sentence like Petr laughs at even the most stupid jokes (besides its at-issue meaning) has a likelihood presupposition

${ }^{3}$ The literature on types of NPIs is alas not totally coherent: we use the label anti-morphicity in the same way as Krifka (1995) and Zwarts (1998). For a different approach to anti-additivity and anti-morphicity see Gajewski (2005) where anti-morphicity is defined via deMorgan equivalence, corresponding to what Krifka, Zwarts, and we call anti-additivity.

${ }^{4}$ But as one of the anonymous reviewers correctly points out, Gajewski classifies neg-raising as an anti-additive environment, not anti-morphic. 
correlating unlikelihood of laughing at $x$ with stupidity of $x$ - the presupposition is triggered by overt even; the covert counterpart of even figures in the licensing of strong and superstrong NPIs.

- The likelihood is related to entailment: logically stronger propositions are less likely then logically weaker propositions.

Technical implementation: even takes two arguments: its prejacent $p$ and a set of alternative propositions (to $p$ ), $q$ ( $q$ being a product of classical Roothian alternative semantics); moreover we follow Crnič (2011) among others in allowing even to move in Logical Form. The formalization of the presupposition is in (6) after Crnič (2014, ex. (4)). It simply requires the prejacent to be less likely than all its focus alternatives.

(6) even $(\mathrm{C})(\mathrm{p}, \mathrm{w})$ is defined only if $\forall \mathrm{q} \in \mathrm{C}: \mathrm{p} \neq \mathrm{q} \rightarrow \mathrm{p}<{ }_{\mathrm{c}} \mathrm{q}$.

Application to example (3): even either scopes below negation - (7a) or with a wider scope than negation - (7b), the alternatives for (7b) are the propositions in (7b'): generated by alternative cardinalities of the NP in (7b). (7a) is a possible scope for even but even's likelihood presupposition wouldn't be satisfied. The alternatives for (7a) are in (7a'), the presupposition of even requires the alternatives to be less likely (and consequently logically stronger) than the prejacent but in this case, the entailment goes the other way round: from $q$ to $p$ and the prejacent cannot be less likely than the alternatives: the alternative $\exists x[\#(X)=2 \wedge$ Product $(X) \wedge \operatorname{GotRotten}(X)]$ entails the prejacent $\exists \mathrm{x}[\#(\mathrm{X})=1 \wedge \operatorname{Product}(\mathrm{X}) \wedge \operatorname{GotRotten}(\mathrm{X})]$, so the alternative is less likely than the prejacent and the presupposition of even is not satisfied. The situation changes when the covert even scopes over negation as in (7b): here the alternatives are in $\left(7 b^{\prime}\right)$ and since the rule of transposition of implication in logic equals the following two formula $(p \rightarrow q) \leftrightarrow(\neg q \rightarrow \neg p)$, the negated alternative $(\neg \exists \mathrm{x}[\#(\mathrm{X})=2 \wedge \operatorname{Product}(\mathrm{X}) \wedge \operatorname{GotRotten}(\mathrm{X})])$ and all other alternatives with higher cardinalities are implied by the prejacent $\neg \exists x[\#(X)=1$ $\wedge$ Product $(\mathrm{X}) \wedge$ GotRotten $(\mathrm{X})]$ in the same way the positive $p$ entails $q$; and because of that the unlikelihood presupposition of even is satisfied. The presupposition treatment of $a n i+$ its associates then predicts likelihood/entailment sensitivity of $a n i$, which is exactly what was tested in the experiment described further.

(7) a. $\neg \exists \mathrm{x}[$ even $[\#(\mathrm{X})=1 \wedge \operatorname{Product}(\mathrm{X}) \wedge \operatorname{GotRotten}(\mathrm{X})]]$

b. $\quad$ even $[\neg \exists \mathrm{x}[\#(\mathrm{X})=1 \wedge \operatorname{Product}(\mathrm{X}) \wedge \operatorname{GotRotten}(\mathrm{X})]]$

a. $\quad \mathrm{q}=\{\exists \mathrm{x}[\#(\mathrm{X})=2 \wedge \operatorname{Product}(\mathrm{X}) \wedge \operatorname{GotRotten}(\mathrm{X})], \exists \mathrm{x}[\#(\mathrm{X})=3 \wedge \operatorname{Product}(\mathrm{X}) \wedge$ $\operatorname{GotRotten}(\mathrm{X})], \quad \ldots\}$

b. $\quad \mathrm{q}=\{\neg \exists \mathrm{x}[\#(\mathrm{X})=2 \wedge \operatorname{Product}(\mathrm{X}) \wedge \operatorname{GotRotten}(\mathrm{X})], \neg \exists \mathrm{x}[\#(\mathrm{X})=3 \wedge \operatorname{Product}(\mathrm{X})$ $\wedge \operatorname{GotRotten}(\mathrm{X})], \ldots\}$

Another prediction of our approach then is that ani is (if it scopes over the negation) expected to associate with weak elements in most cases where the weak 
elements (due to the lexical semantics of the verb) entail in a positive case the other alternatives. This fits nicely with the discussed collocations of ani (recall: expressions denoting bottom ends of cardinal scales or minimal speech contributions). On the other hand, if the lexical semantics of the predicate is such that the entailment is reversed, an association with strong elements is predicted to be possible. For such a case, consider a natural example in (8) where the predicate stačit 'be enough' reverses the logical entailment (against the predicate as $z$ kazit 'get rotten' in (3), where the entailment - in the negated variant - goes from alternatives $n$ to $n+1$ inductively; in the case of predicates like be enough the entailment goes from $n$ to $n$ - 1 inductively). In example (8), if 100 million is not enough, then 100 million minus one Euro is also not enough but not the other way round. This explains why ani in (8) can associate with the high end of a scale without problems.

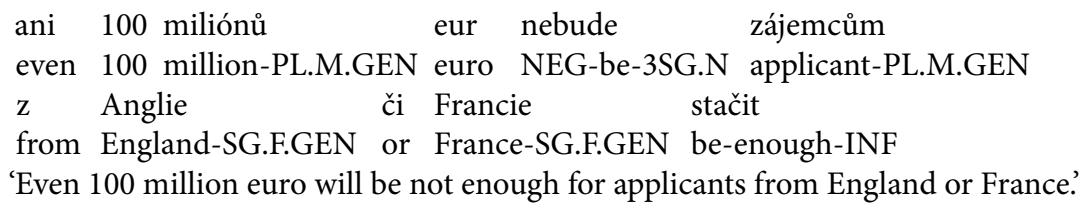

We follow Crnič (2011) and Krifka (1995) in describing the polarity licensing in terms of likelihood. This pragmatic treatment of NPIs licensing is different from the purely semantic approach to NPIs as in Zwarts (1998). Our main reason for adopting the pragmatic theory of NPI licensing is its flexibility, allowing us to deal with cases of ani licensing in non-monotonic (non-entailing) contexts. Consider alternatives like JJohn didn't become a priest, John didn't become a bishop, John didn't become a pope\}. The alternatives are logically independent but are sorted by likelihood and as we will discuss in detail in Section 2.1.2, Czech speakers strongly favor ani with the least likely alternatives ( $a$ priest in this context) even among such logically independent alternative propositions. We think that such subtle sensitivity is beyond the reach of purely semantic theories of NPI licensing.

\section{Experiment}

This section focuses on a relation between the likelihood and scopal properties of Czech ani 'NEG-even' and its NPI-behaviour as they were tested in the experiment. We experimentally tested ani in several environments so-called conditions; specifically, we tested (i) whether Czech ani behaves as a superstrong NPI; (ii) whether its occurrence depends on the likelihood presupposition; and (iii) whether there is a relation between the conditions and the covert even scopal properties.

First, we introduce the design of the experiment and then the results we obtained. We can foreshadow already that the experiment confirmed that Czech 
ani (i) behaves like a superstrong NPI and that (ii) it carries unlikelihood presupposition.

\subsection{Method}

\subsubsection{Procedure and Participants}

The experiment consisted of two parts, one immediately following the other. The experiment contained tested sentences as items, and controlled sentences as fillers. We used Latin square design in both experimental parts, which prevented any item appearing twice, i.e., each item occured only once in the whole experiment for each subject, whereas individual conditions cycled with the subjects. The order of items and fillers was presented to each participant randomly but in such a way that an item always alternated with a filler.

The experiment was run on Ibex and participants performed the experiment online (the web address of the experiment: spellout.net/ibexexps/iveta/ october_2018/experiment.html). The experiment began with instructions, then practice items; after the practice, subjects judged real items and fillers.

The experiment was distributed by HUME Lab - the Experimental Humanities Laboratory at Masaryk University to the students enrolled in a course focused on experimental methods taught by HUME Lab. The students received course credit for their participation. 50 Czech native speakers participated in the experiment.

\subsubsection{Materials}

The experiment consisted of truth value judgment task: the experiment tested whether a sentence fits a given context, with the context preceding the target sentence. We used a 5-point Likert scale from 1 (absolutně nepríijatelná věta 'completely unacceptable sentence') to 5 (věta je naprosto $v$ poř́ádku 'completely acceptable sentence'). The experiment consisted of two parts.

Part 1: there were 18 items and 18 fillers in the first part of the experiment in two sub-conditions: (i) items with $i$ 'even', and (ii) items with ani 'not even'. The sample item including both sub-conditions is in (9).

(9) Context: Students received a list of recommended literature, consisting of six books, for an exam. However, passing the exam is not always influenced by the number of books studied.

a. Petr přečetl i šest knih, ale zkoušku neudělal. TOP 'Petr even read the six books, but he failed the exam.'

b. Petr nepřečetl ani šest knih a zkoušku udělal. TOP 'Petr didn't even read the six books, and he passed the exam.'

c. Petr přečetl i tři knihy, ale zkoušku neudělal.

'Petr even read three books, but he failed the exam.' 
d. Petr nepřečetl ani tři knihy a zkoušku udělal. MID

'Petr didn't even read three books, and he passed the exam.'

e. Petr přečetl i jednu knihu, ale zkoušku neudělal. LOW

'Petr even read one book, but he failed the exam.'

f. Petr nepřečetl ani jednu knihu a zkoušku udělal. LOW

'Petr didn't even read one book, and he passed the exam.'

This is a typical type of condition where the theory predicts that ani should associate only with weak elements (the condition LOW) since the main predicate préríst is downward monotonic: if Petr read $n$ books, he read $n$-1, etc. In this study, we deal with the second sub-condition concerning ani because we explore NPI-behaviour of ani; for a related debate concerning the PPI behaviour of $i$ see Dočekal and Šafratová (2019). For that reason, we limit our discussion (in the present paper) only to conditions with ani 'NEG-even', and leave the investigation of $i$ 'even' aside. A sample glossed item restricted to the second sub-condition (negative even) is in (10). ${ }^{5}$ All items were tested in three conditions:

1. TOP: top of the scale (10a)

2. MID: middle of the scale (10b)

3. LOW: low of the scale (10c)

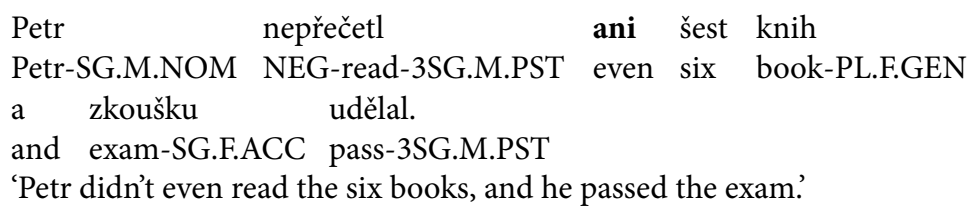

b. Petr

nepřečetl

ani tři knihy

Petr-SG.M.NOM NEG-read-3SG.M.PST even three book-PL.F.ACC

a zkoušku udělal.

and exam-SG.F.ACC pass-3SG.M.PST

'Petr didn't even read three books, and he passed the exam.'

c. Petr nepřečetl ani jednu knihu

Petr-SG.M.NOM NEG-read-3SG.M.PST even one book-SG.F.ACC

a zkoušku udělal.

and exam-SG.F.ACC pass-3SG.M.PST

'Petr didn't even read one book, and he passed the exam.'

There is an ad hoc scale given by the context. The logical scale for the contextual alternatives is in (11-a): the stronger alternative always entails the weaker alternatives. Because of the contextual entailment, the likelihood is ordered as

\footnotetext{
${ }^{5}$ The context used in the examples (9) and (10) remains the same.
} 
in (11b): the stronger alternative is less likely than the weaker alternatives and the ranking or likelihood respects the entailment.

(11) a. $\mathrm{x}$ read 6 books $\rightarrow \mathrm{x}$ read 5 books $\rightarrow \ldots \rightarrow \mathrm{x}$ read 1 book

b. $\mathrm{x}$ read 6 books $<_{\mathrm{C}} \mathrm{x}$ read 5 books $<_{\mathrm{C}} \ldots .<_{\mathrm{C}} \mathrm{x}$ read 1 book

The alternative $x$ read 6 books is the strongest one in the given context because it entails all alternatives, and at the same time, it is the least likely alternative because $x$ read 6 books is less likely than other alternatives. The likelihood respects entailment in this case; therefore the strongest alternatives $x$ read 6 books is also the least likely alternative. ${ }^{6}$ We used other contextual and logical scale in the experiment too, as given by way of examples in (12).

(12) a. contextual scale: write a thesis $\rightarrow$ write two chapters $\rightarrow$ write notes

b. logical scale: 3 visitors come $\rightarrow 2$ visitors come $\rightarrow 1$ visitor come

The theoretical framework predicts that NPI ani should associate with the most likely alternative in the positive scale (as in (11)), which becomes the least likely alternative when the proposition is negated as in the items of the experiment: recall that $x \neg$ reads 1 book entails all alternative propositions $x \neg$ reads $n$ books and consequently is the least likely among the alternatives. Therefore, we expected that the condition LOW should be the most acceptable and we predict low acceptability of the condition MID and the condition TOP.

Part 2: there were 32 items and 32 fillers in this part in the same two subconditions as in the first part: (i) items with $i$ 'even', and (ii) items with ani '(not) even'. The sample item including both sub-conditions is in (13).

(13) Context: The hierarchy of the Catholic Church consists of various ranks. The lowest rank is a priest, the highest rank is pope and somewhere in the middle is a bishop. The mother is deeply religious and wants her son to become a priest. However, the father strongly opposes her and wants their son to study mathematics.

a. Syn se nakonec nestal ani knězem.

NEG-ANI

'In the end, the son didn't become NEG-even a priest.'

b. Syn se nakonec nestal ani papežem.

NEG-ANI-TOP

'In the end, the son didn't become NEG-even the pope.'

${ }^{6}$ The likelihood respects entailment, but if there is no entailment, the likelihood can be manipulated in any way.

In other words, the likelihood depends on the presence or the absence of entailment. If there is an entailment between alternatives, the likelihood is given by the entailment; however, if the entailment is missing, the likelihood between alternatives can be manipulated by the context. For instance, the proposition Archaeologists will come to the party is logically independent of the proposition Linguists will come to the party, i.e., neither one of them entails the other, but we can imagine that either archaeologists or linguists are a more likely group to come to the party. Therefore, if there is no entailment between these two propositions, we can manipulate a context and cause one proposition to be more likely than the other proposition. 
c. Jestli se syn stane ani knězem, otec bude mrzutý.

COND-ANI

'If the son becomes neg-even a priest, his father will be annoyed.'

d. Otec nechce, aby se jeho syn stal ani knězem.

NR-ANI

'The father doesn't want his son to become NEG-even a priest.'

e. Matka nechce, aby se její syn stal i papežem.

NR-I

'The mother doesn't want her son to become even the pope.'

f. Syn se nakonec nestal i papežem.

NEG-I

'In the end, the son didn't become even the pope.'

g. Jestli se syn stane i papežem, otec bude velmi naštvaný.

COND-I-TOP

'If the son becomes even the pope, the father will be annoyed.'

h. Jestli se syn stane i knězem, otec bude velmi naštvaný.

'If the son becomes even a priest, the father will be annoyed.'

COND-I-BOT

We used logical and contextual scales in this part, as in the first part of the experiment. All items were tested in all conditions, but in the present study, we focus on a subset of conditions exploring ani 'NEG-even'. A discussion concerning the PPI $i$ can be found in Dočekal and Šafratová (2019); a related investigation of ani and Neg-Raising is reported in Dočekal and Dotlačil $(2016,2018)$.

- NEG-ANI: ani in a simple negative sentence associating with the bottom of scale (14a)

- NEG-ANI-TOP: ani in a simple negative sentence associating with the bottom of scale (14b)

- COND-ANI: ani in the antecedent of the conditional associating with the bottom of scale (14c)

A sample glossed item restricted to these 3 conditions is the following: ${ }^{7}$

(14) a. Syn se nakonec nestal ani son-SG.M.NOM SE in-the-end NEG-become-3SG.M.PST even knězem.

priest-SG.M.INS

'In the end, the son didn't become even a priest.'

b. Syn se nakonec nestal ani

son-SG.M.NOM SE in-the-end NEG-become-3SG.M.PST even

papežem.

pope-SG.M.INS

'In the end, the son didn't become even the pope.'

c. Jestli se syn stane ani

if SE son-SG.M.NOM become-3.SG.M.FUT even

knězem, otec bude mrzutý.

priest-SG.M.INS father-SG.M.NOM be-SG.M.FUT annoyed-3SG.M.NOM

'If the son becomes even a priest, his father will be annoyed.'

7 The context remains the same for both examples (13) and (14). 
The contextual scale of the alternatives given in the context is the following:

(15) a. $\mathrm{x}$ become the pope $\rightarrow \mathrm{x}$ become a bishop $\rightarrow \mathrm{x}$ become a priest

b. $\mathrm{x}$ become the pope $<_{\mathrm{C}} \mathrm{x}$ become a bishop $<_{\mathrm{C}} \mathrm{x}$ become a priest

The context is manipulated in such a way that the alternative $x$ become the pope is the strongest one, and it entails $x$ become a bishop and $x$ become a priest because in most prototypical contexts. If somebody becomes the pope, he had to have become a bishop and a priest before. At the same time, the alternative $x$ become the pope is the least likely alternative among other alternatives in the context. We again used mostly negated (or at least downward entailing/antiadditive conditions), so we expected that ani will associate with weak elements too since in $\mathrm{DE}$ contexts the weak associates become logically strongest and the least likely. Nevertheless, the alternatives are strictly logically independent (see our discussion at the end Section 1.1 above).

\subsection{Results}

We present here the statistical output of both parts of the experiment and the figures demonstrating the results. Responses were modeled using linear mixed-effects models (in R package lmer).

The fillers were non-controversially grammatical/acceptable (in their context), and we checked whether the average of each participant's responses to ungrammatical fillers was lower than the average of their responses to grammatical fillers. The difference was at least 1.5 on the Likert scale, which indicates that all the participants successfully passed the fillers; hence, we kept all the subjects in the subsequent analysis.

\subsubsection{Part 1}

To begin, we present results from the first part of the experiment. We constructed a mixed linear model, which tested whether subjects' answers can be predicted from a condition (fixed effect) and whether the conditions are statistically significantly different. The model had one predictor, i.e., the reference level condition: the condition MID and all fixed effects were significant (the model also included random effects for subjects and items). The model shows that the condition LOW was statistically significantly different from the reference level condition MID and the condition TOP statistically significantly differs from the reference level condition MID as well. ${ }^{8}$

The statistical output of the model is the following:

\footnotetext{
${ }^{8}$ Three stars in the last column indicate the high statistical difference between the given condition and the reference level condition. The significance code is as follows: ' $* * *$ ' 0.001 ; '**' 0.01 ; ‘’ 0.05 ; $: 0.1$; and no mark is 1 .
} 
Table 1. The statistical output: Part 1

\begin{tabular}{|l|c|c|c|c|c|}
\hline \multicolumn{1}{|l|}{ Fixed effects: } \\
\hline & Estimate Std. & \multicolumn{1}{|c|}{ Error } & \multicolumn{1}{c|}{ df } & \multicolumn{1}{c|}{ t value } & $\operatorname{Pr}(>|\mathbf{t}|)$ \\
\hline (Intercept) & 3.4901 & 0.2020 & 16.7490 & 17.274 & $4.17 \mathrm{e}-12^{* * *}$ \\
\hline Condition Low & 0.7269 & 0.1445 & 382.5049 & 5.031 & $7.53 \mathrm{e}-07^{* * *}$ \\
\hline Condition Top & -0.7346 & 0.1445 & 382.5049 & -5.084 & $5.79 \mathrm{e}-07^{* * *}$ \\
\hline
\end{tabular}

Table 2. Correlation of Fixed Effects: Part 1

\begin{tabular}{|l|c|c|}
\hline & (Intr) & Cndtnl \\
\hline Condition Low & -0.358 & \\
\hline Condition Top & -0.358 & 0.500 \\
\hline
\end{tabular}

Error-bars of the individual conditions of the first part of the experiment are shown in Figure 1.9

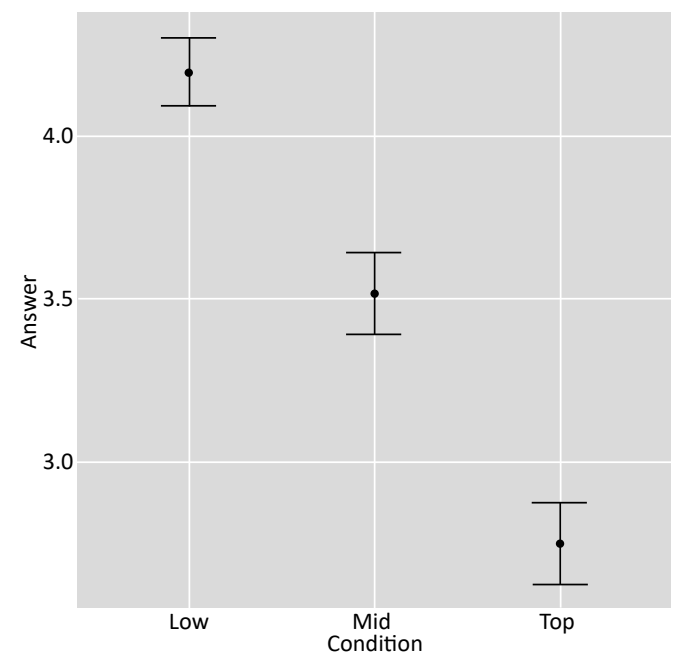

Figure 1. Results of Part 1

The statistical output and descriptive statistics show:

(i) the high preference for weak expressions associating with ani;

(ii) due to negation reversing the direction of the entailment and the likelihood, ani is a weak expression, but associates with the least likely alternative from the set of alternatives (the bottom of the scale: the condition LOW)

${ }^{9}$ Error-bars don't show the real variation among participants, but rather the variation, which from the data, one would expect can occur if repeating the experiments. Namely, they show the expected variation among experiments. 
whereas the association with the most likely alternative leads to strong un-acceptability (the top of the scale: the condition TOP);

(iii) in-between-acceptability for the MID condition is surprising: we assume that subjects used some rescue strategy as domain shrinking to satisfy the universal unlikelihood presupposition (we will discuss this point further bellow).

\subsubsection{Part 2}

We constructed the mixed linear model for the second part of the experiment too, as in the first part of the experiment. The model had one predictor - reference level condition: the condition NEG-TOP. And again, each condition statistically significantly differs from the reference level condition; specifically, the condition NEG was significantly different from the condition NEG-TOP and the condition COND-POS significantly differs from the condition NEG-TOP too (the model again included random effects for subjects and items): NEG was more acceptable (positive $t$ value), COND-POS was considered worse.

The statistical output of the second part of the experiment is the following:

Table 3. The statistical output: Part 2

\begin{tabular}{|l|c|c|r|r|r|}
\hline Fixed effects: & \multicolumn{1}{|l|}{} \\
\hline & Estimate Std. & \multicolumn{1}{|l|}{ Error } & \multicolumn{1}{l|}{ df } & \multicolumn{1}{c|}{ value } & $\operatorname{Pr}(>|\mathbf{t}|)$ \\
\hline (Intercept) & 2.2084 & 0.1275 & 96.5876 & 17.326 & $2 \mathrm{e}-16^{* * *}$ \\
\hline Condition CondPos & -0.5888 & 0.1377 & 532.7231 & -4.275 & $2.26 \mathrm{e}-05^{\star * *}$ \\
\hline Condition Neg & 1.2854 & 0.1367 & 541.2981 & 9.404 & $2 \mathrm{e}-16^{* * *}$ \\
\hline
\end{tabular}

Table 4. Correlation of Fixed Effects: Part 2

\begin{tabular}{|l|c|c|}
\hline & (Intr) & Cndtnl \\
\hline Condition CondPos & -0.536 & \\
\hline Condition Neg & -0.536 & 0.499 \\
\hline
\end{tabular}

Error-bars of the individual conditions of the second part of the experiment are shown in Figure 2. 


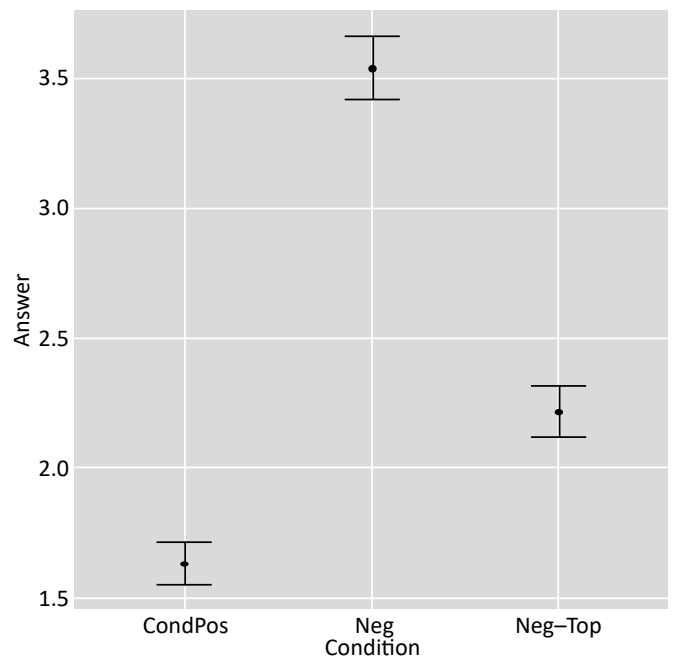

Figure 2. Results of Part 2

The statistical output and descriptive statistics show:

(i) ani prefers to associate with weak elements (the acceptability of the condition NEG was higher than the acceptability of the condition NEG-TOP) which confirms the results of the first part of the experimental;

(ii) ani is un-acceptable in the positive antecedent of the conditionals (the condition COND-POS), ani really needs the anti-morphic environment, DE/ anti-additivity is not enough to license it.

\subsubsection{Overall results}

To summarize the first and the second part of the experiment, the descriptive statistics showing the means and medians of the individual conditions is the following:

Table 5. Means and medians of the individual conditions

\begin{tabular}{|l|l|c|c|}
\hline & Condition & Means & Medians \\
\hline 1 & CondPos & 1.632653 & 1 \\
\hline 2 & Low & 4.190476 & 5 \\
\hline 3 & Mid & 3.517007 & 4 \\
\hline 4 & Neg & 3.540816 & 5 \\
\hline 5 & Neg-Top & 2.214286 & 2 \\
\hline 6 & Top & 2.755102 & 3 \\
\hline
\end{tabular}

Error-bars of the individual conditions of both experimental parts are shown in Figure 3. 


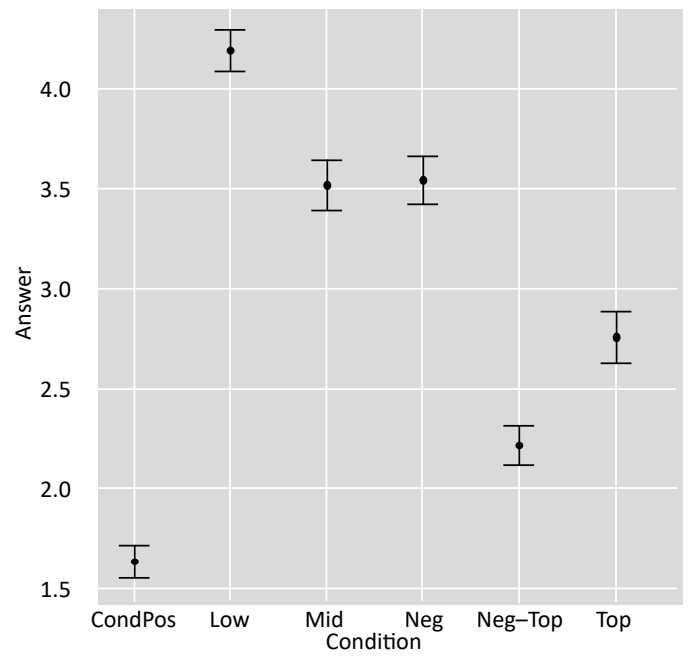

Figure 3. Overall results

The summary clearly shows the interplay of both semantic factors (required anti-morphic environment $\rightarrow$ low acceptability of COND-POS) and pragmatic factors: ani associates with weak elements on scales which due to the antimorphic environment are interpreted as the least likely (theoretical explanation in the scope theory of even: even has wider scope than the negation and compares the prejacent with negated alternatives).

\section{Summary}

Let us summarize now: both the experimental findings and the way they fit into the assumed semantic-pragmatic theory of NPIs licensing. Let's begin with the clearest contrasts:

1. From the highest acceptability of LOW and low acceptability of TOP, it is clear that a purely semantic theory of ani NPIs cannot be right: both conditions tested the acceptability of ani NPIs in negated sentences but only in LOW condition, where ani associated with weak elements, did they fulfill the unlikelihood presupposition of the covert even. This shows that purely semantic concepts as anti-morphicity are not enough to explain ani's behaviour. A similar conclusion can be drawn from even lower acceptability of NEG-TOP.

2. In our experiment we observed relatively high acceptability of NegRaising licensing of ani NPIs (the observed mean was 2.628, still better than NEG-ANI-TOP, e.g.) but because we discuss this issue elsewhere (Dočekal and Dotlačil 2016, 2018), we don't go into further details in the current article simply to save the space. In a nutshell, the Neg-Raising licensing confirms the semantic nature of ani licensing since it shows non-local dependency of the 
NPI and its licensor, something that would be hard to explain in purely syntactic approaches to NPI licensing.

3. Relatively interesting is the 3.5 (mean) acceptability of MID: from the data we gathered in the experiment, we believe it can be hypothesized that some sort of domain shrinking strategy is the source of this (unexpectedly) high acceptability. Because otherwise the universal nature of even presupposition would be violated and another type of NPI theory would have to be accepted, we would like to blame an independent reason like pragmatic shrinking of the domain, as most of the experiment's results seem to be in accordance with the theory. Nevertheless, we plan to design a follow-up experiment to investigate this issue more thoroughly.

4. From the point of view of movement theory of even, it seems surprising that subjects were unable to associate high scalar items with ani (again the conditions TOP and NEG-TOP). Theoretically, this can be explained via the obligatory wide scope of even over negation. But why this should be the case, is to some extent unclear (the scope theory of even predicts that a schematic scope such as $[\neg[$ even ... strong element $]]$ should be acceptable despite its measured low acceptability rate.

To summarize the whole experiment, we can say that Czech ani NPIs behave like a relatively nice example of a superstrong class of NPIs: (i) they need anti-morphic environments (totally un-acceptable in purely Downward Entailing environments: COND-POS); (ii) their licensing is of a pragmatic nature too: only unlikelihood prejacents are good as their hosts.

\section{References}

Błaszczak Joanna (2001). Investigation into the Interaction between the Indefinites and Negation. Berlin: Akademie Verlag. DOI: https://doi.org/10.1515/9783050080093.

Crnič Luka (2011). Getting even. Cambridge, MA: Massachusetts Institute of Technology. $\mathrm{PhD}$ dissertation.

Crnič Luka (2014). Against a dogma on NPI licensing. In The Art and Craft of Semantics: A Festschrift for Irene Heim 1, Luka Crnič and Uli Sauerland (eds.), 117-45. Cambridge, MA: MIT Working Papers in Linguistics.

Český národní korpus - SYN2010. Ústav Českého národního korpusu, Faculty of Arts Charles University, Praha. URL: www.korpus.cz, accessed January 20, 2019.

Dočekal Mojmír, Dotlačil Jakub (2016). Experimental evidence for Neg-Raising in Slavic. Linguistica 56(1), 93-109. DOI: https://doi.org/10.4312/linguistica.56.1.93-109.

Dočekal Mojmír, Dotlačil Jakub (2018). When is not-believing believing that not? Proceedings of Sinn und Bedeutung 21, 387-399.

Dočekal Mojmír, Šafratová Iveta (2019). Even hypothesis of PPIs Licensing: An experimental study. In Language Use and Linguistic Structure, Joseph Emonds, Markéta Janebová, and Ludmila Veselovská (eds.), 253-273. Olomouc: Palacký University. 
von Fintel Kai (1999). NPI licensing, Strawson entailment, and context dependency. Journal of Semantics 16(2), 97-148. DOI: https://doi.org/10.1093/jos/16.2.97.

Gajewski Jon R. (2005). Neg-Raising: Polarity and presupposition. Cambridge, MA: Massachusetts Institute of Technology. PhD dissertation.

Gajewski Jon R. (2007). Neg-Raising and polarity. Linguistics and Philosophy 30(3): 289-328. DOI: https://doi.org/10.1007/s10988-007-9020-z.

Gajewski Jon R. (2011). Licensing strong NPIs. Natural Language Semantics 19(2): 109-148. DOI: https://doi.org/10.1007/s11050-010-9067-1.

Krifka Manfred (1995). The semantics and pragmatics of polarity items. Linguistic Analysis 25(3-4): 209-257.

Lahiri Utpal (1998). Focus and negative polarity in Hindi. Natural Language Semantics 6(1), 57-123. DOI: https://doi.org/10.1023/A:1008211808250.

Zwarts Frans (1998). Three types of polarity. In Plurality and Quantification. Studies in Linguistics and Philosophy Series, Fritz Hamm and Erhard Hinrichs (eds.), 177238. Dordrecht: Kluwer Academic Publisher. DOI: https://doi.org/10.1007/97894-017-2706-8_5.

Mojmír Dočekal, Iveta Šafratová

Department of Linguistics and Baltic Languages

Faculty of Arts

Masaryk University

Arna Nováka 1/1

60200 Brno

docekal(at)phil.muni.cz

safratova(at)mail.muni.cz 
